\title{
CHRONOLOGY OF SIR WILLIAM OSLER'S LIFE
}

1849 (July 12) Born in Bond Head, Upper Canada (later Canada West, now the Province of Ontario), youngest son of Rev. Featherstone Lake Osler and Ellen Free (Pickton).

1857 (March) Family moves to Dundas, the very western tip of Lake Ontario.

1866 (January) Enters Trinity College School, an independent school for boys, then in Weston and now in Port Hope. Meets Rev. W. A. Johnson, founder and warden of Trinity College School and Dr. James Bovell, medical director appointed by the bishop. Both men had a great influence upon the young Osler.

1867 (autumn) Enters Trinity College, Toronto, with the idea of becoming a clergyman. Later, he abandons the idea to become a physician.

1868 (autumn) Enrolls in Toronto School of Medicine.

1869 (February) "Christmas and the Microscope" published in Hardwicke's Science-Gossip, his first published paper.

1870 (autumn) Enters the McGill Medical Faculty in Montreal because of the better clinical opportunities it had to offer. Meets Dr. Robert Palmer Howard, his mentor.

1872 (spring) Graduates from McGill.

$1872-1874$ Spends two years studying in Europe visiting clinics in London, Berlin, and Vienna. 
1874 (July) Receives an offer to lecture upon the Institutes of Medicine at the McGill Medical Faculty.

1875 (April) Upon the death of Dr. M. Drake, he is officially appointed professor of medicine at the McGill Medical Faculty.

1878 (summer) Visits Britain (London and Edinburgh) with George Ross to take his membership of the Royal College of Physicians and to work in clinical medicine.

1879 (May-July) Starts teaching clinical medicine at the Montreal General Hospital. During the following five years he teaches physiology and pathology in XXII the winter season and clinical medicine in the summer.

1884 (spring) Spends time in Europe (London, Berlin, Leipzig) and accepts an appointment as professor of clinical medicine at the University of Pennsylvania.

(October) Appointed professor of clinical medicine at the University of Pennsylvania. This is the beginning of a twenty-one-year period of work and residence in the United States.

1888 (September) Appointed professor of medicine and physician in chief at the new Johns Hopkins Medical School and Hospital in Baltimore, Maryland.

1889 (May) "Aequanimitas," a valedictory address, delivered to the graduates in medicine of the University of Pennsylvania.

1891 (June) "Doctor and Nurse" delivered to the first class of graduates from the Training School for Nurses at the Johns Hopkins Hospital.

1892 (February) Principles and Practice of Medicine published.

(May) Marries Grace Linzee (Revere), widow of Dr. Samuel W. Gross of Philadelphia.

(October) "Teacher and Student" delivered at the opening of the new medical buildings of the University of Minnesota.

(December) "Physic and Physicians as Depicted in Plato" delivered at the meeting of the Johns Hopkins Hospital Historical Club.

1894 (May) "The Leaven of Science" delivered at the opening of the Wistar Institute of Anatomy and Biology at the University of Pennsylvania.

1895 (January) "Teaching and Thinking-The Two Functions of a Medical School" delivered at the opening of the new building at the McGill Medical Faculty.

(December 28) His son, Edward Revere Osler, born. 
1897 (February, June) "Nurse and Patient" delivered in February at the commencement exercises of the Training School for Nurses at the Philadelphia Hospital, and again in June at the commencement exercises of the Training School for Nurses at the Johns Hopkins Hospital.

1899 (September) "After Twenty-Five Years" delivered before the faculty and students of the Medical Faculty, McGill University.

1901 (January) "Books and Men" delivered at the opening of the new building of the Boston Medical Library.

1902 (September) "Chauvinism in Medicine" delivered before the Canadian Medical Association.

XXIII

1903 (October) "The Mater-Word in Medicine" delivered at the opening of the new laboratories for physiology and pathology of the University of Toronto, thirty-five years after he studied there.

(December) "The Hospital as a College" delivered at the Academy of Medicine, New York.

1904 (August) Accepts the offer of the Regius Chair of Medicine at Oxford University.

1905 (February) "The Fixed Period," a farewell address, delivered at the commencement exercises before the alumni, faculty, and students of Johns Hopkins University. (April) "The Student Life," a farewell address to Canadian and American medical students, delivered at McGill University, and later the same month at the University of Pennsylvania. (April) "Unity, Peace, and Concord," a farewell address to leaders of the medical profession of the United States, delivered at the annual meeting of the Medical and Chirurgical Faculty of Maryland, Baltimore. (May) "L'Envoi," a speech at a farewell dinner in New York, delivered before leaders of the medical profession of Canada and the United States. (June) The Oslers move to Oxford. Appointed regius professor of medicine at Oxford University.

(October) "Sir Thomas Browne" delivered at the Physical Society of Guy's Hospital, London.

1910 (July) "Man's Redemption of Man: A Lay Sermon" delivered at McEwan Hall, Edinburgh.

1911 (June) Baronetcy conferred by King George V. 
1913 (April) "A Way of Life" delivered to Yale students. His last visit to the United States.

1917 (August) The Oslers' son Revere killed in Belgium while on active service as an officer in the Royal Field Artillery.

1919 (May) "The Old Humanities and the New Science" delivered before the Classical Association of Oxford. Osler was president of the Association.

(July) Has a sharp attack of bronchial pneumonia.

(December 29) Dies aged 70.

1920 (January 1) A simple service at Christ Church Cathedral in Oxford held for

XXIV

"one of the most greatly beloved physicians of all time" (Cushing).

CHRONOLOGY

\section{References}

Cushing, Harvey. The Life of Sir William Osler (1925). Reprint. New York: Oxford University Press, 1977.

Golden, Richard L. and Charles G. Roland, eds. Sir William Osler, An Annotated Bibliography with Illustrations. San Francisco: Jeremy Norman and Co., 1988.

Nation, Earl F., Charles G. Roland, and John P. McGovern. An Annotated Checklist of Osleriana. Kent, Ohio: Kent State University Press, 1976. 
OSLER'S

"A Way of LifE"

ANd Other Addresses,

WITH COMMENTARY AND

Annotations 
